\begin{tabular}{l|l} 
Votaice & e-ISSN: 2655-9404 p-ISSN: 2721-8376 \\
Vol. 3 No. 2, Juni 2020 & DOI: 10.20473/ntr.v3i2.20535 \\
\hline
\end{tabular}

Article history: Submitted 15 April 2020 ; Accepted 13 May 2020; Available online 1 June 2020.

\title{
Pengenaan Tarif Pajak Penghasilan Final pada Usaha Mikro Kecil Berdasarkan PP Nomor 23 Tahun 2018
}

\author{
Nindy Aprillya Rachman \\ nindy.aprillya.rachman-2016@fh.unair.ac.id \\ Universitas Airlangga
}

\begin{abstract}
In order to increase state revenue, the government issues a new policy through Government Regulation Number 23 Year 2018. The Government Regulation provides facilities to tax payers who indirectly target Small Micro Enterprises to be able to develop their businesses. This Government Regulation is a substitute regulation of Government Regulation Number 46 Year 2013 which is final. There are several differences between those two Government Regulations, one of which is a very striking change in the rate of tariff and a binding period for taxpayers. This study aims to analyze the implementation of the application of income tax rates in Government Regulation Number 46 Year 2013 and Government Regulation Number 23 Year 2018. This research is a legal research uses a statute approach and conceptual approach. The result of this legal research, it is known that the imposition of final income tax rates in Government Regulation Number 46 Year 2013 and Government Regulation Number 23 Year 2018 on Micro Small Businesses cannot be done immediately. The Small Micro Business must be fullfill certain characteristics and levels / groups in order to be subject to final income tax.

Keywords: Micro Small Business; Final Income Tax; Legal Protection of Taxpayers.
\end{abstract}

\footnotetext{
Abstrak

Dalam rangka meningkatkan pendapatan negara, pemerintah menerbitkan kebijakan baru melalui Peraturan Pemerintah Nomor 23 Tahun 2018. Peraturan Pemerintah tersebut memberikan fasilitas kepada wajib pajak yang secara tidak langsung menyasar kepada Usaha Mikro Kecil untuk dapat mengembangkan usahanya. Peraturan Pemerintah ini merupakan peraturan pengganti dari Peraturan Pemerintah Nomor 46 Tahun 2013 yang bersifat final. Terdapat beberapa perbedaan di antara kedua Peraturan Pemerintah tersebut, salah satunya adalah perubahan besaran tarif yang sangat mencolok serta adanya jangka waktu yang mengikat bagi wajib pajak. Penelitian ini bertujuan untuk menganalisis implementasi penerapan tarif pajak penghasilan pada Peraturan Pemerintah Nomor 46 Tahun 2013 dan Peraturan Pemerintah Nomor 23 Tahun 2018. Penelitian ini merupakan penelitian hukum yang disusun dengan menggunakan pendekatan perundang-undangan dan pendekatan konseptual. Dari penelitian hukum ini, diketahui bahwa pengenaan tarif pajak penghasilan final dalam Peraturan Pemerintah Nomor 46 Tahun 2013 dan Peraturan Pemerintah Nomor 23 Tahun 2018 terhadap Usaha Mikro Kecil tidak dapat dilakukan secara serta merta. Usaha Mikro Kecil tersebut harus memenuhi karakteristik serta tingkatan/ golongan tertentu agar dapat dikenakan pajak penghasilan final.

Kata Kunci: Usaha Mikro Kecil; Pajak Penghasilan Final; Perlindungan Hukum Wajib Pajak.
} 


\section{Pendahuluan}

Dalam kehidupan sehari-hari, kita tidak terlepas oleh adanya pajak yang merupakan sumber pendapatan paling besar bagi Negara Republik Indonesia. Pajak adalah perspektif ekonomi jika dipahami sebagai beralihnya sumber daya dari sektor privat kepada sektor publik. ${ }^{1}$ Pengertian pajak dijelaskan di dalam Pasal 1 ayat (1) Undang-undang Nomor 28 Tahun 2007 tentang Perubahan Ketiga atas Undang-undang Nomor 6 Tahun 1983 tentang Ketentuan Umum dan Tata Cara Perpajakan yang menyatakan bahwa:

"Pajak adalah kontribusi wajib kepada negara yang terutang oleh orang pribadi atau badan yang bersifat memaksa berdasarkan undang-undang, dengan tidak mendapat imbalan secara langsung dan digunakan untuk keperluan negara bagi sebesar-besarnya kemakmuran rakyat"

Pungutan pajak bersifat wajib dan dapat dipaksakan karena didasarkan pada undang-undang, namun wajib pajak akan tidak mendapatkan timbal balik dari pajak secara langsung melainkan mendapatkan timbal balik untuk jangka panjang yang diterima secara kolektif bersama dengan masyarakat lain. Sebagaimana hal ini telah dinyatakan di dalam Pasal 23A Undang-undang Dasar Negara Republik Indonesia Tahun 1945 bahwa:

"pajak dan pungutan lain yang bersifat memaksa untuk keperluan negara diatur dengan undang-undang".

Pasal ini menunjukkan bahwa pungutan pajak tidak bisa dilakukan tanpa adanya peraturan perundang-undangan yang mengaturnya. Hal ini sebagai salah satu bentuk perlindungan bagi wajib pajak. Pungutan pajak mengurangi penghasilan atau kekayaan individu, tetapi sebaliknya, merupakan penghasilan masyarakat yang kemudian dikembalikan lagi kepada masyarakat. ${ }^{2}$

Melihat besarnya pengaruh perpajakan terhadap perekonomian dan pembangunan negara, maka seharusnya negara dapat memaksimalkan pendapatannya melalui sektor perpajakan, salah satunya di bidang pajak penghasilan. Setiap wajib pajak yang telah memperoleh penghasilan akan

\footnotetext{
1 Adrian Sutedi, Hukum Pajak (Sinar Grafika 2016).[1].

2 Erly Suandy, Hukum Pajak (Salemba Empat 2017).[ 8].
} 
dikenakan pajak penghasilan. Melihat hal tersebut, maka sangat penting bagi negara untuk merangkul pelaku Usaha Mikro Kecil yang merupakan kelompok usaha dalam perekonomian Indonesia yang memiliki jumlah paling besar dan tengah berkembang pesat di Indonesia untuk ikut serta berkontribusi kepada negara. Usaha Mikro Kecil memiliki peran yang krusial bagi perekonomian Indonesia.

Dasar pemikiran diterapkannya pajak penghasilan final yaitu untuk menyederhanakan pengenaan pajak penghasilan dari usaha dan untuk memudahkan beban administrasi bagi wajib pajak dalam rangka meningkatkan peran Usaha Mikro Kecil agar dapat lebih mudah untuk melaksanakan kewajiban perpajakannya. Kriteria Usaha Mikro Kecil yang tertuang di Pasal 6 Undangundang Nomor 20 Tahun 2008 tentang Usaha Mikro, Kecil, dan Menengah adalah sebagai berikut:

a. Kriteria Usaha Mikromemiliki kekayaan bersih paling banyak Rp.50.000.000,00 (lima puluh juta rupiah) tidak termasuk tanah dan bangunan tempat usaha; atau memiliki hasil penjualan tahunan paling banyak Rp.300.000.000,00 (tiga ratus juta rupiah).

b. Kriteria Usaha Kecil memiliki kekayaan bersih lebih dari Rp.50.000.000,00 (lima puluh juta rupiah) sampai dengan paling banyak Rp.500.000.000,00 (lima ratus juta rupiah) tidak termasuk tanah dan bangunan tempat usaha; atau memiliki hasil penjualan tahunan lebih dari Rp.300.000.000,00 (tiga ratus juta rupiah) sampai dengan paling banyak Rp.2.500.000.000,00 (dua miliar lima ratus juta rupiah).

Pajak penghasilan final khusus dikenakan pada wajib pajak yang memiliki peredaran bruto atau omzet di bawah angka Rp.4.800.000.000,00 (empat miliar delapan ratus juta rupiah) dalam setahun. Hal ini sesuai dengan kriteria Usaha Mikro Kecil yang dijelaskan di Pasal 6 Undang-undang Nomor 20 Tahun 2008 tentang Usaha Mikro, Kecil, dan Menengah.

Pada 1 Juli 2018, pemerintah mengeluarkan Peraturan Pemerintah Nomor 23 Tahun 2018. Di dalamnya memuat tarif baru untuk pajak penghasilan final bagi 
Usaha Mikro Kecil. Bukan hanya perubahan tarif, tetapi Peraturan Pemerintah ini juga memiliki beberapa perbedaan dengan ketentuan pada Peraturan Pemerintah Nomor 46 Tahun 2013. Di antaranya yaitu, Peraturan Pemerintah Nomor 23 Tahun 2018 menawarkan alternatif pengenaan pajak kepada wajib pajak yang dapat meringankan wajib pajak.

Kebijakan penerapan tarif pajak penghasilan final berdasarkan Peraturan Pemerintah Nomor46 Tahun 2013 dan Peraturan Pemerintah Nomor 23 Tahun 2018. Upaya hukum atas kebijakan penerapan tarif pajak penghasilan final berdasarkan Peraturan Pemerintah Nomor 46 Tahun 2013 dan Peraturan Pemerintah Nomor 23 Tahun 2018.

\section{Kebijakan penerapan tarif pajak penghasilan final berdasarkan Peraturan} Pemerintah Nomor 46 Tahun 2013 dan Peraturan Pemerintah Nomor 23 Tahun 2018

Berdasarkan pada ketentuan di dalam Pasal 4 ayat (2) Undang-undang Pajak Penghasilan, dijelaskan bahwa penghasilan yang dapat dikenakan pajak yang bersifat final diatur berdasarkan pada Peraturan Pemerintah. Oleh karena itu diberlakukan Peraturan Pemerintah Nomor 23 Tahun 2018 yang menggantikan Peraturan Pemerintah Nomor 46 Tahun 2013 yang mengatur mengenai Pajak Penghasilan atas Penghasilan dari Usaha yang Diterima atau Diperoleh Wajib Pajak yang Memiliki Peredaran Bruto Tertentu.

Peraturan Pemerintah Nomor 46 Tahun 2013 secara tidak langsung ditujukan kepada Usaha Mikro Kecil, sebab di dalamnya mengatur tentang pengenaan pajak bagi wajib pajak pribadi dan badan yang jumlah penghasilan yang didapat dari usahanya memiliki omzet di bawah Rp.4.800.000.000,00 dalam waktu 1 tahun pajak, hal ini sesuai dengan kriteria Usaha Mikro Kecil yang telah ditetapkan di dalam Pasal 6 Undang-undang Nomor 20 Tahun 2008.

Peraturan Pemerintah Nomor 23 Tahun 2018 memangkas tarif pajak yang sebelumnya diatur dalam Peraturan Pemerintah Nomor 46 Tahun 2013 yang awalnya sebesar $1 \%$ kini turun menjadi $0,5 \%$ sehingga sedikit mengurangi beban wajib pajak. Kriteria wajib pajak yang dapat dikenai tarif pajak penghasilan final 
0,5\% ini hampir sama dengan yang terdapat dalam Peraturan Pemerintah Nomor 46 Tahun 2013, berdasarkan Pasal 3 ayat (1) Peraturan Pemerintah Nomor 23 Tahun 2018, untuk wajib pajak yang bisa dikenakan tarif sebesar 0,5\% yaitu:

“wajib pajak yang memiliki peredaran bruto tertentu yang dikenai pajak penghasilan final sebagaimana dimaksud dalam Pasal 2 ayat (1) merupakan wajib pajak orang pribadi dan wajib pajak badan berbentuk koperasi, persekutuan komanditer, firma, atau perseroan terbatas".

Dalam Peraturan Pemerintah Nomor 23 Tahun 2018 ini, tidak hanya mengatur terkait penurunan tarif tetapi juga memberikan kebebasan kepada wajib pajak untuk memilih dikenakan tarif pada Peraturan Pemerintah Nomor 23 Tahun 2018 atau langsung dikenakan tarif normal pada Pasal 17 Undang-undang Pajak Penghasilan. Pasal 17 Undang-undang Pajak Penghasilan memiliki fungsi untuk mengatur besarnya tarif yang diberlakukan oleh pemerintah terhadap wajib pajak serta menjelaskan secara rinci mengenai tarif yang digunakan dalam menghitung penghasilan kena pajak.

Berbeda dengan ketentuan tarif 1\% dalam Peraturan Pemerintah Nomor 46 Tahun 2013, tarif pajak sebesar 0,5\% ini tidak dapat dinikmati untuk jangka waktu selamanya. Di dalam Pasal 5 ayat (1) Peraturan Pemerintah Nomor 23 Tahun 2018, dijelaskan bahwa terdapat jangka waktu bagi wajib pajak apabila menggunakan Peraturan Pemerintah Nomor 23 Tahun 2018, yaitu:

a) 7 tahun bagi wajib pajak orang pribadi;

b) 4 tahun bagi wajib pajak berbentuk koperasi, $\mathrm{CV}$, atau firma; dan

c) 3 tahun bagi wajib pajak berbentuk Perseroan Terbatas.

Apabila wajib pajak lebih memilih menggunakan Peraturan Pemerintah Nomor 23 Tahun 2018, maka wajib pajak berhak untuk menggunakan tarif 0,5\% dengan jangka waktu yang telah ditentukan di dalam Pasal 5 ayat (1) Peraturan Pemerintah Nomor 23 Tahun 2018 tersebut. Sedangkan apabila wajib pajak lebih memilih menggunakan tarif normal dalam Pasal 17 Undang-undang Pajak Penghasilan, maka wajib pajak tidak bisa lagi memanfaatkan tarif pajak final 0,5\% dalam Peraturan Pemerintah Nomor 23 Tahun 2018. Jangka waktu yang dimaksud berlaku sejak tahun pajak wajib pajak mulai terdaftar atau sejak saat 
berlakunya Peraturan Pemerintah Nomor 23 Tahun 2018 ini. Berikut merupakan tabel persamaan dan perbedaan antara Peraturan Pemerintah Nomor 46 Tahun 2013 dan Peraturan Pemerintah Nomor 23 Tahun $2018 .{ }^{3}$

\begin{tabular}{|c|c|c|}
\hline Poin & $\begin{array}{l}\text { Peraturan Pemerintah Nomor } 46 \\
\text { Tahun } 2013\end{array}$ & $\begin{array}{l}\text { Peraturan Pemerintah Nomor } 23 \\
\text { Tahun } 2018\end{array}$ \\
\hline Subye & $\begin{array}{l}\text { - Wajib pajak orang pribadi } \\
\text { - Wajib Pajak Badan tidak ter- } \\
\text { masuk bentuk usaha tetap }\end{array}$ & $\begin{array}{l}\text { - Wajib Pajak Orang Pribadi } \\
\text { - Wajib Pajak Badan Tertentu } \\
\text { - PT } \\
\text { - CV dan Firma } \\
\text { - Koperasi }\end{array}$ \\
\hline $\begin{array}{l}\text { Pengecualian } \\
\text { Subyek Pajak }\end{array}$ & $\begin{array}{l}\text { Wajib Pajak orang pribadi yang } \\
\text { melakukan kegiatan usaha } \\
\text { perdagangan dan/atau jasa yang } \\
\text { dalam usahanya menggunakan: } \\
\text { a.Sarana atau prasarana yang } \\
\text { dapat dibongkar pasang baik } \\
\text { yang menetap maupun tidak } \\
\text { menetap; dan } \\
\text { b.Sebagian atau seluruh tem- } \\
\text { pat untuk kepentingan umum } \\
\text { yang tidak diperuntukkan bagi } \\
\text { tempat usaha atau berjualan } \\
\text { Wajib Pajak badan yang: } \\
\text { a.belum beroperasi secara } \\
\text { komersial; atau } \\
\text { b.dalam jangka waktu } 1 \text { ta- } \\
\text { hun setelah beroperasi secara } \\
\text { komersial memperoleh pere- } \\
\text { daran bruto melebihi Rp } 4,8 \mathrm{M}\end{array}$ & $\begin{array}{l}\text { a. Wajib Pajak yang memilih un- } \\
\text { tuk dikenai PPh berdasarkan } \\
\text { tarif Pasal } 17 \text { ayat (1) huruf a, } \\
\text { Pasal } 17 \text { ayat (2a), atau Pasal } \\
\text { 31E UU PPh. } \\
\text { b. Persekutuan komanditer atau } \\
\text { firma yang dibentuk oleh be- } \\
\text { berapa Wajib Pajak orang } \\
\text { pribadi yang memiliki keahl- } \\
\text { ian khusus menyerahkan jasa } \\
\text { sejenis dengan jasa sehubun- } \\
\text { gan dengan pekerjaan. } \\
\text { c. Wajib Pajak Badan yang mem- } \\
\text { peroleh fasilitas Psl 31A UU } \\
\text { PPh dan PP 94 } \\
\text { d. Bentuk Usaha Tetap }\end{array}$ \\
\hline Batasan Omzet & \multicolumn{2}{|c|}{$\begin{array}{l}\text { Menerima penghasilan dari usaha, tidak termasuk penghasilan dari } \\
\text { jasa sehubungan dengan pekerjaan bebas, dengan peredaran bruto } \\
\text { tidak melebihi Rp } 4,8 \mathrm{M} \text { dalam } 1 \text { Tahun Pajak. }\end{array}$} \\
\hline $\begin{array}{l}\text { Pengecualian } \\
\text { Objek Pajak }\end{array}$ & \multicolumn{2}{|c|}{$\begin{array}{l}\text { a. Penghasilan yang diterima atau diperoleh dari jasa sehubungan } \\
\text { dengan pekerjaan bebas; } \\
\text { b. Penghasilan yang diterima atau diperoleh diluar negeri; } \\
\text { c. Usaha yang atas penghasilannya telah dikenai Pajak Penghasilan } \\
\text { yang bersifat final dengan ketentuan peraturan perundang-un- } \\
\text { dangan perpajakan tersendiri; dan } \\
\text { d. Penghasilan yang dikecualikan sebagai objek pajak. }\end{array}$} \\
\hline
\end{tabular}




\begin{tabular}{|c|c|c|}
\hline Tarif & $1 \%$ & $0,5 \%$ \\
\hline Batasan Waktu & Tidak Ada & $\begin{array}{l}\text { 1. WP Orang Pribadi: } 7 \text { tahun } \\
\text { 2. CV/Firma/Koperasi: } 4 \text { tahun } \\
\text { 3. PT: } 3 \text { tahun } \\
\text { Dihitung sejak: } \\
\text { Wajib Pajak lama: Tahun Pajak } \\
\text { PP berlaku } \\
\text { Wajib Pajak baru: Tahun Pajak } \\
\text { terdaftar }\end{array}$ \\
\hline Penyetoran & $\begin{array}{l}\text { a. Setor Sendiri } \\
\text { b. Dibebaskan dari pemotongan/ } \\
\text { pemungutan pihak lain dalam } \\
\text { hal dapat menunjukkan Surat } \\
\text { Keterangan Bebas ke Kantor } \\
\text { Pelayanan Pajak }\end{array}$ & $\begin{array}{l}\text { a. Setor Sendiri ; atau } \\
\text { b. Dipotong atau dipungut oleh } \\
\text { Pemotong atau Pemungut } \\
\text { Pajak, dengan mengajukan } \\
\text { Surat Keterangan ke Kantor } \\
\text { Pelayanan Pajak }\end{array}$ \\
\hline $\begin{array}{l}\text { Penentuan } \\
\text { Pengenaan } \\
\text { Pajak }\end{array}$ & $\begin{array}{l}\text { Didasarkan pada peredaran bruto } \\
\text { dari usaha dalam } 1 \text { tahun dari } \\
\text { Tahun Pajak terakhir sebelum } \\
\text { Tahun Pajak yang bersangkutan. }\end{array}$ & $\begin{array}{l}\text { Tetap. } \\
\text { Penegasan untuk Wajib Pajak } \\
\text { Orang Pribadi yang status Pisah } \\
\text { harta dan Memilih Terpisah } \\
\text { (2 NPWP) harus berdasarkan } \\
\text { penggabungan sesuai prinsip } \\
\text { keluarga sebagai satu kesatuan } \\
\text { ekonomis. }\end{array}$ \\
\hline DPP & \multicolumn{2}{|c|}{ Jumlah peredaran bruto setiap bulan } \\
\hline
\end{tabular}

Implementasi Penerapan Tarif Pajak Penghasilan Final bagi Pemerintah dan Wajib Pajak

Tarif pajak final yang diatur dalam Peraturan Pemerintah baik dalam Peraturan Pemerintah Nomor 46 Tahun 2013 maupun Peraturan Pemerintah Nomor 23 Tahun 2018 merupakan tarif pajak yang tetap dikenakan kepada wajib pajak tanpa memandang kondisi wajib pajak untung atau rugi. Hal ini tentu memiliki dampak bagi implementasi penerapan tarif pajak penghasilan bagi pemerintah dan wajib pajak.

Ketika diberlakukannya Peraturan Pemerintah Nomor 46 Tahun 2013, tarif pajak final yang dikenakan adalah sebesar 1\%, sedangkan ketika berlaku Peraturan Pemerintah Nomor 23 Tahun 2018 tarif pajak dipangkas 
hingga $0,5 \%$. Ketika dilihat dari sudut pandang tarif pajak yang bersifat final yang tidak memperdulikan untung ruginya wajib pajak, maka Peraturan Pemerintah Nomor 23 Tahun 2018 disini lebih menguntungkan daripada Peraturan Pemerintah Nomor 46 Tahun 2013. Tarif yang lebih rendah semakin memudahkan wajib pajak dalam menjalankan kewajiban perpajakannya sehingga akan menarik minat para pelaku Usaha Mikro Kecil untuk menjalankan kewajibannya dalam membayar pajak. Hal ini bertujuan untuk mendorong peran serta Usaha Mikro Kecil dalam pembangunan berkelanjutan, memberi kesempatan untuk ikut serta berkontribusi kepada negara melalui perpajakan serta meningkatkan jumlah wajib pajak. Jumlah Usaha Mikro Kecil di Indonesia yang besar akan mendorong pembangunan berkelanjutan apabila diiringi dengan kesadaran masyarakat atas kewajiban perpajakannya. Maka dari itu, diperlukan adanya peraturan khusus yang memudahkan bagi Usaha Mikro Kecil demi mengoptimalkan penerimaan pajak negara dari sektor Usaha Mikro Kecil.

Pada prinsipnya Usaha Mikro Kecil tidak mendapatkan banyak keuntungan dalam waktu cepat, melainkan keuntungan yang tipis tetapi berkesinambungan. Maka dari itu, keuntungan yang tipis tersebut akan semakin habis apabila wajib pajak menggunakan tarif pajak pada Peraturan Pemerintah Nomor 46 Tahun 2013 karena dasar penghitungannya bukan berdasarkan dari keuntungan (neto), namun berdasarkan pada harga barang yang diperdagangkan (bruto). Walaupun tarif pajak dalam Peraturan Pemerintah Nomor 23 Tahun 2018 juga dihitung berdasarkan peredaran bruto, tetapi tarif yang ditawarkan oleh Peraturan Pemerintah ini lebih rendah daripada Peraturan Pemerintah Nomor 46 Tahun 2013. Selain itu, Peraturan Pemerintah Nomor 46 Tahun 2013 juga tidak memperkenankan wajib pajak untuk kembali dikenakan ketentuan tarif Pasal 17 Undang-undang Pajak Penghasilan sebelum wajib pajak tersebut memperoleh omzet lebih dari Rp.4.800.000.000,00. Oleh karena itu, wajib pajak yang omzetnya naik-turun di kisaran Rp.4.800.000.000,00 akan kesulitan untuk berganti-ganti metode penghitungan pajak penghasilan. 
Berlakunya Peraturan Pemerintah Nomor 23 Tahun 2018 memberikan pilihan kepada wajib pajak untuk memilih menggunakan Peraturan Pemerintah Nomor 23 Tahun 2018 itu sendiri atau langsung dikenai Pasal 17 Undangundang Pajak Penghasilan. Hal ini memberikan kesempatan kepada Usaha Mikro Kecil yang belum dapat menyelenggarakan pembukuannya dengan baik. Penerapan pajak penghasilan final sebesar 0,5\% memberikan kemudahan karena penghitungan pajak menjadi lebih sederhana, dengan begitu Usaha Mikro Kecil dapat menyiapkan pembukuannya sebelum akhirnya kembali ke Pasal 17 Undangundang Pajak Penghasilan setelah jangka waktu yang telah ditetapkan dalam Pasal 5 ayat (1) Peraturan Pemerintah Nomor 23 Tahun 2018 habis. Walaupun Peraturan Pemerintah Nomor 23 Tahun 2018 memberikan pilihan kepada wajib pajak, namun bukan berarti wajib pajak dapat berpindah-pindah pengenaan tarifnya sesuai keinginannya. Misalkan dari awal wajib pajak memilih untuk dikenakan tarif pajak berdasarkan Peraturan Pemerintah Nomor 23 Tahun 2018, maka wajib pajak tidak boleh meminta agar dikenakan tarif pada Pasal 17 Undang-undang Pajak Penghasilan sebelum jangka waktunya habis atau setelah omzet yang diterima wajib pajak di atas Rp.4.800.000.000,00. Begitu pula sebaliknya, apabila dari awal wajib pajak memilih untuk dikenakan tarif berdasarkan Pasal 17 Undang-undang Pajak Penghasilan, maka wajib pajak tidak dapat lagi meminta dikenakan tarif 0,5\% dari Peraturan Pemerintah Nomor 23 Tahun 2018.

\section{Karakteristik Usaha Mikro Kecil yang Dikenakan Pajak Penghasilan Final}

Dalam buku Pandji Anoraga diterangkan bahwa secara umum, sektor usaha memiliki karakteristik sebagai berikut: ${ }^{4}$

1. Sistem pembukuan yang relatif administrasi pembukuan sederhana dan cenderung tidak mengikuti kaidah administrasi pembukuan standar. Terkadang pembukuan tidak di up to date sehingga sulit untuk menilai kerja usahanya;

2. Margin usaha yang cenderung tipis mengingat persaingan yang sangat tinggi;

3. Modal terbatas; 
4. Pengalaman menejerial dalam mengelola perusahaan masih sangat terbatas;

5. Skala ekonomi yang terlalu kecil sehingga sulit mengharapkan untuk mampu menekan biaya mencapai titik efisiensi jangka panjang;

6. Kemampuan pemasaran dan negosiasi serta diversifikasi pasar sangat terbatas;

7. Kemampuan untuk sumber dana dari pasar modal terendah, mengingat keterbatasan dalam sistem administrasinya. Untuk mendapatkan dana di pasar modal, sebuah perusahaan harus mengikuti sistem administrasi standar dan harus transparan.

Dari sini jika dikaitkan dengan karakteristik wajib pajak yang dapat dikenakan tarif pajak penghasilan final berdasarkan Peraturan Pemerintah Nomor 23 Tahun 2018, maka karakteristik Usaha Mikro Kecil yang dapat dikenakan pajak penghasilan final yaitu Usaha Mikro Kecil yang memiliki omzet tidak lebih dari Rp.4.800.000.000,00 dalam setahun dan belum memiliki sistem pembukuan yang memenuhi standar. Peran Peraturan Pemerintah dalam hal ini yaitu memberikan waktu bagi Usaha Mikro Kecil untuk menyiapkan pembukuan dengan baik agar usahanya dapat semakin berkembang. Selain itu Usaha Mikro Kecil yang memiliki modal terbatas dalam menjalankan usahanya sehingga mereka berada dalam skala ekonomi yang terlalu kecil yang menyebabkan kemampuan pemasaran dan negosiasi serta diversifikasi pasar sangat terbatas. Maka Usaha Mikro Kecil yang ingin dikenai tarif pajak penghasilan final harus memiliki karakteristikkarakteristik tersebut.

\section{Tingkatan Usaha yang Dikenakan Pajak Penghasilan Final}

Untukdapatmenentukanusaha yang dapat dikenakan tarif pajak penghasilan final, maka diperlukan penggolongan atau tingkatan usaha berdasarkan kriteria tertentu. Hal ini bertujuan agar pengenaan pajak penghasilan lebih efektif. Berikut adalah tabel kriteria Usaha Mikro, Kecil, Menengah, dan Usaha Besar berdasarkan Aset dan Omzet:

1) Usaha mikro memiliki aset maksimal Rp.50.000.000,00 tidak termasuk tanah dan bangunan tempat usaha dan memiliki omzet maksimal Rp.300.000.000,00 dalam setahun.

2) Usaha kecil memiliki aset lebih dari Rp.50.000.000,00 sampai dengan Rp.500.000.000,00 tidak termasuk tanah dan bangunan serta omzet lebih dari Rp.300.000.000,00 sampai dengan Rp.2.500.000.000,00. 
3) Usaha menengah memiliki aset lebih dari Rp.500.000.000,00 sampai dengan Rp.10.000.000.000,00 tidak termasuk tanah dan bangunan dan memiliki omzet lebih dari Rp.2.500.000.000,00 sampai dengan Rp.50.000.000.000,00.

4) Usaha besar yang memiliki aset yang tidak termasuk tanah dan bangunan tempat usaha lebih dari Rp.10.000.000.000,00 dan ozmet lebih dari Rp.50.000.000.000,00.

Sebelumnya telah dijelaskan bahwa Peraturan Pemerintah Nomor 23 Tahun 2018 memberikan alternatif kepada wajib pajak untuk memilih dikenakan tarif dalam Peraturan Pemerintah Nomor 23 Tahun 2018 atau dikenakan tarif dalam Pasal 17 Undang-undang Pajak Penghasilan. Bagi wajib pajak yang memilih untuk dikenakan tarif pajak penghasilan berdasarkan tarif dalam Pasal 17 Undangundang Pajak Penghasilan, maka akan terdapat presentase penarifan terhadap lapisan penghasilan usahanya. Berikut adalah tabel tarif pajak yang diterapkan atas penghasilan kena pajak bagi wajib pajak orang pribadi dalam negeri:

1) Lapisan Kena Pajak sampai dengan Rp.50.000.000,00 (lima puluh juta rupiah) dikenai tarif pajak sebesar $5 \%$;

2) Di atas Rp.50.000.000,00 (lima puluh juta rupiah) sampai dengan Rp.250.000.000,00 (dua ratus lima puluh juta rupiah) dikenai tarif pajak sebesar $15 \%$;

3) Di atas Rp.250.000.000,00 (dua ratus lima puluh juta rupiah) sampai dengan Rp.500.000.000,00 (lima ratus juta rupiah) dikenai tarif pajak sebesar 25\%;

4) Di atas Rp.500.000.000,00 (di atas lima ratus juta) dikenai tarif pajak sebesar $30 \%$.

\section{Perlindungan Hukum Bagi Wajib Pajak}

Seiring dengan meningkatnya jumlah wajib pajak, maka semakin bertambah pula potensi terjadinya sengketa pajak. Penyelesaian sengketa pajak tersebut tentu sebisa mungkin harus adil dengan proses yang cepat dan murah. Pajak yang telah ditetapkan ke dalam bentuk undang-undang memiliki sifat yang memaksa karena mengandung sanksi hukum berupa sanksi administratif ataupun sanksi pidana. ${ }^{5}$ Dalam Pasal 23A Undang-undang Dasar 1945, terkandung suatu asas legalitas yang merupakan salah satu asas dalam negara hukum yang bertujuan

\footnotetext{
5 Etty Rochaeti, 'Perlindungan Hukum Bagi Wajib Pajak Dalam Penyelesaian Sengketa Pajak’ [2012] Jurnal Wawasan Hukum.[499].
} 
untuk memberikan perlindungan bagi wajib pajak dalam memenuhi keperluan negara. Perlindungan hukum tersebut bertujuan melindungi wajib pajak dari kemungkinan terjadinya sengketa pajak yang diakibatkan oleh dikeluarkannya peraturan yang memberatkan wajib pajak.

Terdapat dua macam bentuk perlindungan hukum, yaitu perlindungan hukum yang dilakukan di awal sebagai bentuk pencegahan terjadinya sengketa dan juga perlindungan hukum yang dilakukan di akhir sebagai bentuk penyelesaian sengketa yang terlanjur terjadi. Sebagaimana dikatakan Philipus M. Hadjon, perlindungan hukum bagi rakyat ada 2 (dua) macam yaitu: 1) perlindungan hukum yang preventif dan 2) perlindungan hukum yang represif. ${ }^{6}$

\section{a. Perlindungan Hukum Preventif}

Apabila wajib pajak merasakan keberatan atas suatu keputusan pemerintah, maka wajib pajak memiliki kesempatan untuk mengajukan keberatan ataupun pendapatnya sebelum suatu keputusan pemerintah tersebut disahkan. Perlindungan hukum preventif memiliki peranan yang cukup penting bagi tindakan pemerintahan yang didasarkan pada kebebasan bertindak karena mendorong pemerintah untuk bersikap hati-hati dalam mengambil keputusan yang didasarkan pada diskresi. ${ }^{7}$ Perlindungan hukum preventif tidak lepas dari hukum pajak formal yang mengandung peraturan-peraturan megenai cara mewujudkan hukum materiil yang terkandung di dalam suatu peraturan perundang-undangan.

Dalam memungut pajak, institusi pemungut pajak hendaknya memerhatikan berbagai asas pemungutan pajak seperti asas pemungutan pajak “The Four Cannons Maxims Taxation" yang dikemukakan oleh Adam Smith. ${ }^{8}$ Keempat asas tersebut di antaranya adalah asas Equality (Persamaan), asas Certainly (Kepastian Hukum),

\footnotetext{
6 ibid.[501].
}

7 I Kadek Sumadi dan Naniek Noviari, 'Perlindungan Hukum Bagi Wajib Pajak Dan Penanggung Pajak Dalam Sengketa Pajak' (2014) 9 Jurnal Ilmiah Akuntansi dan Bisnis.[123].

8 DJP, 'Asas Pemungutan Pajak <>, Accessed 9 Januari 2020.' (DJP, 2014) <https://www. pajak.go.id/id/asas-pemungutan-pajak> accessed 9 January 2020. 
asas Convenience of Payment (Pemungutan Pajak Tepat Waktu), dan asas Eficiency/ Economic of Collections (Efisiensi). Berikut adalah asas-asas yang relevan dengan pokok bahasan ini yaitu:

\section{Asas Equality}

Asas Equality berarti pemungutan pajak yang dilakukan oleh negara harus sesuai dengan kemampuan dan penghasilan wajib pajak. Negara tidak boleh bertindak diskriminatif terhadap wajib pajak. Disini ditekankan bahwa tidak boleh ada diskriminatif dalam hal pemungutan pajak, maksud dari kesamaan di sini bukanlah sama rata melainkan proporsional. Proporsional berarti pemungutan pajak dilakukan secara seimbang sesuai dengan kemampuan wajib pajak karena wajib pajak memiliki kemampuan ekonomi yang berbeda-beda. Berdasarkan uraian tersebut maka pemungutan pajak penghasilan terhadap Usaha Mikro Kecil telah mencerminkan asas Equality. Pemungutan pajak penghasilan tersebut telah disesuaikan dengan jumlah omzet yang diperoleh oleh Usaha Mikro Kecil dalam waktu satu tahun pajak.

\section{Asas Certainly}

Asas Certainty berarti semua pungutan pajak harus berdasarkan Undangundang, sehingga bagi yang melanggar akan dapat dikenai sanksi hukum. Disini ditekankan bagi wajib pajak untuk menerangkan dengan jelas mengenai waktu, jumlah dan cara pembayaran pajak karena kepastian hukum sangat diutamakan. Terkait dengan pemungutan pajak penghasilan bagi Usaha Mikro Kecil, telah diatur berbagai macam peraturan perundang-undangan sehingga terdapat kepastian hukum terkait pemungutan pajak penghasilan Usaha Mikro Kecil.

\section{b. Perlindungan Hukum Represif}

Perlindungan hukum secara represif bertujuan untuk menyelesaikan suatu sengketa yang telah terlanjur terjadi dengan cara mengajukan ke pengadilan pajak. Dalam perlindungan hukum represif, upaya hukum yang dapat ditempuh oleh wajib pajak untuk menyelesaikan suatu sengketa adalah dengan mengajukan upaya hukum banding dan upaya hukum gugatan ke pengadilan pajak. 
Kedudukan pengadilan pajak dalam kekuasaan kehakiman yaitu pengadilan khusus di bawah Pengadilan Tata Usaha Negara (PTUN). Dalam Pasal 24 ayat (2) Undang-undang Dasar Republik Indonesia Tahun 1945, dijelaskan bahwa di bawah Peradilan Umum, Peradilan Agama, Peradilan Militer, dan Peradilan Tata Usaha Negara, dapat dibentuk pengadilan khusus sesuai dengan Pasal 27 ayat (1) Undang-undang Nomor 48 Tahun 2009 tentang Kekuasaan Kehakiman.

Pengadilan Pajak masuk dalam lingkup Peradilan Tata Usaha Negara karena memiliki kesamaan pada sifat sengketa dan sifat para pihak. Dilihat dari subyek sengketa, keduanya mempertemukan dua subyek yang bersengketa yaitu dari unsur pemerintah yang posisinya sebagai tergugat/terbanding yang putusannya dipersoalkan dan unsur rakyat sebagai perorangan. Dilihat dari obyek sengketa, keduanya mempermasalahkan mengenai keputusan konkrit (ketetapan) dari lembaga pemerintah yang ditujukan kepada individu dimana ketetapan tersebut dianggap telah merugikan rakyat sebagai perorangan.

Pasal 1 angka 5 Undang-undang Nomor 14 Tahun 2002 tentang Pengadilan Pajak menjabarkan mengenai sengketa pajak bahwa sengketa pajak merupakan suatu sengketa yang timbul di bidang perpajakan antara pejabat yang berwenang dengan wajib pajak sebagai akibat karena telah dikeluarkannya suatu keputusan yang dapat diajukan upaya hukum banding atau upaya hukum gugatan kepada pengadilan pajak berlandaskan pada peraturan perundang-undangan perpajakan. Dalam hal ini Paulus Effendi Lotulung menyatakan bahwa perlindungan hukum yang dapat ditempuh dalam hal penyelesaian dan pemutusan sengketa antara rakyat dengan pemerintah dalam menjalankan tugasnya di bidang hukum publik adalah sebagai berikut: ${ }^{9}$

1. Penyelesaian melaluijalur intern administratif, yaitu atasan hierarti dari pejabat yang bersangkutan, jalur ini lazim dikenal dengan sebutan "administratif beroup" atau prosedur pengajuan keberatan.

2. Penyelesaian sengketa yang dilakukan oleh badan-badan peradilan semu,

9 Rochaeti (n 5)., Op.Cit.[502]. 
yang sebetulnya secara struktur-organisatoris merupakan bagian dari pemerintahan.

3. Penyelesaian oleh badan peradilan, yang dapat berupa:

a. peradilan khusus, yaitu masalah pajak, dan

b. peradilan umum.

Dengan demikian dapat disimpulkan bahwa hukum pajak memberikan perlindungan hukum bagi wajib pajak baik dalam peradilan ataupun di luar peradilan. Oleh karena itu terdapat upaya hukum yang disediakan oleh Undangundang Pajak untuk menyelesaikan sengketa perpajakan.

\section{Upaya Hukum Bagi Wajib Pajak}

Tujuan dariadanya hukum adalah untuk memperoleh keadilan, maka hukum pajak yang juga bagian dari 'hukum' itu sendiri harus ditujukan untuk mencapai sebuah keadilan. Sengketa pajak yang telah diajukan kepada Pengadilan Pajak merupakan sebuah proses dalam hukum pajak yang akan memberikan keadilan baik keadilan bagi wajib pajak ataupun keadilan bagi pemerintah yang disini berkedudukan sebagai pemungut pajak. Keadilan dalam proses pemungutan pajak ini haruslah meliputi pembentukan perundang-undangannya, pengenaan pajaknya, pemungutan pajaknya, bahkan dalam pembagian beban yang harus ditanggung oleh wajib pajak yang bersangkutan, serta adanya saluran-saluran hukum yang terbuka bagi wajib pajak untuk mencari suatu keadilan dalam bidang perpajakan. ${ }^{10}$ Dalam pelaksanaan perpajakan, hubungan hukum yang terjalin antara wajib pajak dengan pemungut pajak sangat memungkinkan terjadi perselisihan dan menimbulkan sengketa. Penyelesaian sengketa pajak yang timbul antara Direktur jenderal Pajak dengan wajib pajak dapat diselesaikan melalui 2 (dua) bentuk penyelesaian. ${ }^{11}$

1. Penyelesaian suatu sengketa yang ditangani oleh pihak yang terlibat di dalam

\footnotetext{
10 Wiratni Ahmadi, Perlindungan Hukum Bagi Wajib Pajak Dalam Penyelesaian Sengketa Pajak (Refika Aditama 2006).[67-68].

11 ibid.[72].
} 
sengketa itu sendiri yaitu Direktur jenderal Pajak melalui upaya keberatan dan permohonan pembetulan, vide Pasal 16 dan Pasal 36 Undang-undang Ketentuan Umum Tata Cara Perpajakan.

2. Penyelesaian suatu sengketa yang ditangani oleh pihak yang tidak terlibat di dalam sengketa itu sendiri yaitu Pengadilan Pajak melalui upaya hukum Banding dan dan upaya hukum Gugatan yang terhadap putusan Banding dan Gugatan tersebut para pihak dapat mengajukan Peninjauan Kembali ke Mahkamah Agung.

Jika diuraikan, upaya hukum yang dapat ditempuh oleh Wajib Pajak adalah sebagai berikut: ${ }^{12}$

1. Keberatan

Upaya hukum keberatan adalah upaya hukum yang pertama kali dapat dilakukan oleh wajib pajak atas ketetapan pajak. ${ }^{13}$ Dalam hal Usaha Mikro Kecil merasa dirugikan oleh diterbitkannya suatu keputusan pemerintah, maka Usaha Mikro Kecil memiliki hal untuk mengajukan keberatan terhadap hal tersebut. Dalam Pasal 25 ayat (1) Undang-undang Ketentuan Umum dan Tata Cara Perpajakan telah diatur mengenai hak bagi wajib pajak untuk mengajukan keberatan kepada Direktur Jenderal Pajak. Wajib pajak hanya dapat mengajukan keberatan terhadap materi atau isi dari surat ketetapan pajak, yang meliputi jumlah kerugian berdasarkan ketentuan peraturan perundang-undangan perpajakan, besarnya pajak, atau terhadap materi atau isi dari pemotongan atau pemungutan pajak. ${ }^{14}$ Selain diatur di dalam Pasal 25 Undang-undang Ketentuan Umum dan Tata Cara Perpajakan, pengajuan keberatan juga diatur di dalam Peraturan Menteri Keuangan Republik Indonesia Nomor 202/PMK.03/2015 tentang Tata Cara Pengajuan dan Penyelesaian Keberatan yang merupakan perubahan atas Peraturan Menteri Keuangan Nomor 9/PMK.03/2013 tentang Tata Cara Pengajuan dan Penyelesaian Keberatan.

\footnotetext{
12 DJP, 'Penyelesaian Sengketa Pajak' (DJP).

${ }^{13}$ Richard Burton Wirawan ilyas, Hukum Pajak, Teori, Analisis, Dan Perkembangannya (2010).[71].

14 DJP, 'Keberatan' (DJP).
} 


\section{Banding}

Berdasarkan pada Pasal 1 angka 6 Undang-undang Nomor 14 Tahun 2002 tentang Pengadilan Pajak, menyatakan bahwa Banding adalah upaya hukum yang dapat dilakukan oleh wajib pajak atau penanggung Pajak terhadap suatu keputusan yang dapat diajukan Banding, berdasarkan peraturan perundangundangan perpajakaan yang berlaku. Banding merupakan upaya hukum lanjutan dari keberatan, objek banding hanya berasal dari penolakan keberatan terhadap penetapan pajak. ${ }^{15}$ Putusan Banding adalah putusan badan peradilan pajak atas banding terhadap Surat Keputusan Keberatan yang diajukan oleh wajib pajak. ${ }^{16}$ Berdasarkan pada Pasal 27 ayat (1) Undang-undang Ketentuan Umum dan Tata Cara Perpajakan, wajib pajak dapat mengajukan permohonan banding hanya kepada badan peradilan atas Surat Keberatan. Apabila setelah dikeluarkannya Surat Keputusan Keberatan oleh Direktur Jenderal Pajak ternyata pelaku Usaha Mikro Kecil sebagai wajib pajak merasa belum puas dengan keputusan keberatan yang diterimanya, Usaha Mikro Kecil dapat mengajukan permohonan banding ke Badan Peradilan Pajak atas Surat Keputusan Keberatan tersebut.

3. Gugatan

Berdasarkan pada Pasal 1 angka 7 Undang-undang Nomor 14 Tahun 2002, menyatakan bahwa Gugatan adalah upaya hukum yang dapat dilakukan oleh wajib pajak yang dalam hal ini adalah Usaha Mikro Kecil atau penanggung pajak terhadap pelaksanaan penagihan pajak atau terhadap keputusan yang dapat diajukan Gugatan berdasarkan peraturan perundang-undangan perpajakan yang berlaku. Upaya hukum banding dan gugatan merupakan dua proses hukum yang tidak bisa dipilih keduanya, melainkan harus salah satunya saja. ${ }^{17}$ Gugatan merupakan sebuah upaya hukum yang bisa diupayakan oleh wajib pajak terhadap suatu penerapan penagihan pajak atau terhadap keputusan yang bisa diajukan gugatan berlandaskan pada peraturan perundang-undangan perpajakan yang berlaku. ${ }^{18}$

${ }_{15}$ Karianton Tampubolon, Praktek, Gugatan, Dan Kasus-KasusPemeriksaan Pajak (Indeks 2013).[24].

16 DJP, 'Banding', <https://www.pajak.go.id/banding>, accessed 28 Oktober 2019.

17 Karianton Tampubolon (n 15).,Op.Cit.[22].

18 DJP, 'Gugatan', <https://www.pajak.go.id/gugatan>, accessed 28 Oktober 2019. 
Gugatan merupakan upaya lanjutan dari ditolaknya pembatalan keputusan yang diajukan oleh wajib pajak. Ketentuan mengenai gugatan telah diuraikan dalam Pasal 40 sampai dengan Pasal 43 Undang-undang Nomor 14 Tahun 2002 tentang Pengadilan Pajak. Objek sengketa pada upaya hukum gugatan tidak memiliki keterkaitan dengan objek pajak pada tahap keberatan maupun banding, upaya hukum gugatan merupakan salah satu upaya penyelesaian sengketa pajak yang hanya dikenal pada tingkat pengadilan pajak. Sumber gugatan berasal dari penagihan pajak oleh pejabat pajak, berupa menerbitkan surat tagihan pajak, surat paksa atau dalam hal tindakan pelaksanaan surat paksa.

4. Peninjauan Kembali

Apabila Usaha Mikro Kecil sebagai wajib pajak merasa bahwa putusan Pengadilan Pajak kurang atau bahkan tidak mencerminkan keadilan maka atas putusan tersebut Usaha Mikro Kecil dapat mengajukan Peninjauan Kembali kepada Mahkamah Agung. Peninjauan Kembali merupakan upaya hukum luar biasa setelah adanya putusan yang berkekuatan hukum tetap (inkracht) atau adanya ketentuan perundang-undangan yang mengatur lain. ${ }^{19}$ Sesuai dengan ketentuan di dalam Pasal 33 ayat (1) Undang-undang Nomor 14 Tahun 2002, Pengadilan Pajak merupakan pengadilan pada tingkat pertama dan tingkat terakhir dalam memeriksa dan memutus sengketa pajak. Sehingga dalam penyelesaian sengketa pajak tidak dikenal istilah kasasi, melainkan Peninjauan Kembali ke Mahkamah Agung.

Usaha Mikro Kecil dapat mengajukan upaya hukum berupa permohonan Peninjauan Kembali kepada Mahkamah Agung terhadap penyelesaian sengketa pajak yang telah diputus oleh Pengadilan Pajak. Peninjauan Kembali ini telah diatur pada Pasal 89 sampai dengan Pasal 93 Undang-undang Nomor 14 Tahun 2002 tentang Pengadilan Pajak yang dijabarkan lebih lanjut dengan Peraturan Mahkamah Agung Republik Indonesia Nomor 3 Tahun 2002 tentang Tata Cara Pengajuan Permohonan Peninjauan Kembali Putusan Pengadilan Pajak. Putusan

${ }^{19}$ Richard Burton, Kajian Aktual Perpajakan (Salemba Empat 2009)., Op.Cit.[74]. 
Pengadilan Pajak yang dapat diajukan Peninjauan Kembali harus memuat alasanalasan selektif yang telah ditetapkan dalam Pasal 91 Undang-undang Nomor 14 Tahun 2002 tentang Pengadilan Pajak.

\section{Kesimpulan}

Diterbitkannya Peraturan Pemerintah Nomor 23 Tahun 2018 menggantikan Peraturan Pemerintah Nomor 46 Tahun 2013 membawa beberapa perubahan dalam hal perpajakan di antaranya dalam hal tarif dan jangka waktu yang mengikat bagi wajib pajak. Pengenaan tarif pajak penghasilan final tidak dapat dilakukan secara serta merta, terdapat berbagai macam karakteristik serta tingkatan usaha yang di dalamnya memuat lapisan penghasilan usaha dan prosentase penarifan sehingga Usaha Mikro Kecil yang akan dikenakan tarif pajak penghasilan final dalam Peraturan Pemerintah Nomor 23 Tahun 2018 harus memenuhi kriteria tersebut.

Terdapat dua perlindungan hukum atas kebijakan penerapan tarif pajak penghasilan final baik berdasarkan Peraturan Pemerintah Nomor 46 Tahun 2013 maupun berdasarkan Peraturan Pemerintah Nomor 23 Tahun 2018 yaitu, perlindungan hukum preventif dan juga perlindungan hukum represif. Perlindungan hukum preventif memuat peraturan perundang-undangan yang mengatur mengenai pedoman perpajakan yang bertujuan untuk menghindari risiko terjadinya sengketa pajak. Selain itu ada juga perlindungan hukum represif yang memuat upaya hukum untuk menyelesaikan sengketa pajak yang telah terjadi, di antaranya yaitu upaya hukum keberatan, upaya hukum banding, upaya hukum gugatan, serta upaya hukum peninjauan kembali.

\section{Daftar Bacaan}

\section{Buku}

Adrian Sutedi, Hukum Pajak (Sinar Grafika 2016).

Erly Suandy, Hukum Pajak (Salemba Empat 2017).

Karianton Tampubolon, Praktek, Gugatan, Dan Kasus-KasusPemeriksaan Pajak (Indeks 2013). 
Pandji Anoraga, Ekonomi Islam Kajian Makro Dan Mikro (Dwi Chandra Wacana 2010).

Richard Burton, Kajian Aktual Perpajakan (Salemba Empat 2009).

Wiratni Ahmadi, Perlindungan Hukum Bagi Wajib Pajak Dalam Penyelesaian Sengketa Pajak (Refika Aditama 2006).

Wirawan ilyas R burton, Hukum Pajak, Teori, Analisis, Dan Perkembangannya (2010).

\section{Laman}

DJP, ‘Keberatan' (DJP).

- - 'Penyelesaian Sengketa Pajak' (DJP).

- - , 'Asas Pemungutan Pajak <>, Accessed 9 Januari 2020.' (DJP, 2014). <https:// www.pajak.go.id/id/asas-pemungutan-pajak> accessed 9 January 2020.

\section{Jurnal}

I Kadek Sumadi dan Naniek Noviari, 'Perlindungan Hukum Bagi Wajib Pajak Dan Penanggung Pajak Dalam Sengketa Pajak’ (2014) 9 Jurnal Ilmiah Akuntansi dan Bisnis.

Rochaeti E, 'Perlindungan Hukum Bagi Wajib Pajak Dalam Penyelesaian Sengketa Pajak' [2012] Jurnal Wawasan Hukum.

PajakStartup, 'Kenali Perbedaan PP 46 dan PP 23', (Pajak Startup, 2019) <https:/ / pajakstartup.com/2019/06/13/kenali-perbedaan-pp-46-dan-pp-23/>, accessed 13 Januari 2020.

How to cite: Nindy Aprillya Rachman, 'Pengenaan Tarif Pajak Penghasilan Final pada Usaha Mikro Kecil Berdasarkan PP Nomor 23 Tahun 2018' (2020) Vol. 3 No. 2 Notaire. 